\title{
The Role of Clusters in the Economic Development of the North-West Regions of Russia
}

\author{
Michael Nikolaev, Denis Malyshev \\ Pskov State University, Finance and Economic Faculty. Address: L. Tolstogo street 4, Pskov, \\ $R U$-180000, Russia
}

\begin{abstract}
The purpose of this paper is to identify problems in innovation and show the role of clusters in the innovative development of the North-West regions of Russia. A characteristic feature of the present stage of economic development of the regions of the Russian Federation is the transition to an innovative socially oriented model of economic development based mainly on the generation, dissemination and use of knowledge. Analysis of policy documents on the federal, as well as macro-regional level regarding issues of strategy of innovative development has shown that the transition to an innovative model of development at the regional level is largely related to formation of clusters:

High-tech clusters in urban areas;

Clusters focused on the deep processing of raw materials and energy with the use of modern technologies in underdeveloped areas;

Tourist and recreational clusters in areas with unique natural and climatic conditions;

Transport and logistics clusters in areas with favorable geographical position.

Great attention to the practical issues of creating clusters is also paid to the regional level. In the strategic development documents of the most of the subjects in the North-West of Russia specific clusters are identified, which could become locomotives of innovation development of the regional economy. The most common in the regions of North-West are the following clusters: forest, tourism, manufacturing, transport and logistics. Analysis of regional practices on creating clusters showed that they are mainly based on the existing specialization of regional economies. Insufficient attention is paid to identify and support of new innovative clusters, and formation of inter-regional clusters.
\end{abstract}

Keywords - cluster, innovative model, regional economic development, region.

\section{INTRODUCTION}

A characteristic feature of the present stage of economic development is the transition to an innovative, socially oriented economic development model, based mainly on the generation, dissemination and use of knowledge.

The strategy of innovative development of Russia up to 2020 resulted in the following thesis: «Russia has ambitious but achievable goals ensuring a high level of well-being, strengthening the country's geopolitical role as one of the global leaders. The only way to achieve these goals is the transition of the economy to an innovative development model» [1]

Great attention is paid to innovative development documents in the regions. Thus, one of the main goals of innovation policy in the North-West should be noted increase the level of innovation of the regional economy and the transition to the principles of the innovation cluster policy.

In the present time there is a contradiction between the high innovation potential of the Russian economy and the extremely low rates of innovation, which causes importance of decision complex of issues to improve its innovation system, designed to ensure the implementation of existing significant innovation potential.

Studies indicate that an unfavorable situation in the sphere of innovation is largely due to an insufficient level of scientific support for management of regional economies through the cluster approach. Therefore actual problem is to identify the problems of innovation at the regional level and systematization of practical experience in the innovation cluster policy in the Russian regions. In this paper mainly the regions of North-West of Russia were studied: Arkhangelsk, Vologda, Kaliningrad, Leningrad, Murmansk, Novgorod, Pskov Region, Republic of Karelia, Republic of Komi, St. Petersburg.

\section{MATERIALS AND METHODS}

\section{Problems in innovation}

Problems of innovation activity in the Russian Federation will be evaluated on the analysis of three groups of indicators: innovative opportunities, indicators of results of innovation activity, as well as indicators of demand for innovation. The indicators of innovative opportunities give an estimate of the current level of economic development of the region, the level of investment opportunities, consumer demand, etc. and include:

- the gross regional product per capita;

- investment in fixed capital per capita;

- average monthly per capita income of the population;

- share of personnel engaged in research and development, in total employment in the economy. 
Indicators of results of innovation activity include:

- share of innovative products in the total volume of production;

- number of advanced production technology;

- number of patents;

- number of patents for utility models.

Indicators of demand for innovation include:

- expenditure on technological innovation, in $\%$ of gross regional product;

- number of used advanced technologies;

- share of organizations implementing technological innovations.

The choice of these parameters, on the one hand, is quite clear, as there are some studies on innovations, which have been used this method [2], and on the other hand, this choice is determined by the availability of information from existing statistical sources [3].

This paper presents a comparative analysis of innovation activity in the North-West Federal District in 2005 and 2010.

For integrated assessment of innovation activity in the regions of North-West for each selected group of indicators we calculated integral index (IP) as follows:

$$
I P=\sum_{i=1}^{n} \alpha_{i} \times B_{i}
$$

Where IP - an integral index as the sum of points for the region;

$\alpha_{i}$ - share of the $\mathrm{i}$-index;

$\mathrm{B}_{\mathrm{i}}$ - evaluating point of the $\mathrm{i}$-index, belonging to the group.

The share of each indicator received the same, i.e. for the integral indicator of innovation potential and integral indicator of innovation activity, it was 0.25 (used 4 indicators), and for the integral indicator of the demand for innovation - 0.33 (used 3 indicators). Evaluating points are based on the normalization of the absolute values of the indicators included in the integral index.

Systematization of practical experience in cluster policy in the regions of Russia

In this direction of research such methods are widely used as systematization, synthesis and grouping. The purpose of the analysis was to identify aspects of the creation of regional innovation clusters.

At the first stage the analysis of the legal and program documents was performed at the federal level. It concerned the issues surrounding the use of clusters as a tool for implementing the strategy of innovative development at the regional level.

From the point of view of development methodology for strategy of innovative development at the regional level special interest are positions of federal documents concerning the creation system of strategic planning, covering three levels of management. The strategy of innovative development of Russia belongs to the first, the federal, level. The second level includes strategies of federal districts, which are developed in accordance with the strategic documents and state programs. These strategies are designed to ensure the coordination of the support and promotion of regional innovation activities. It also provides large projects of interregional importance. The third level includes strategy of socioeconomic development of subjects of the Russian Federation and the regional strategy of innovative development. Further analysis of methodology for strategic planning at the level of federal districts was performed.

Methodology of strategic planning is actively developed at the regional level. The analysis shows that all of the documents regulating the sphere of strategic planning in the regions can be divided into two groups:

- documents regulating the procedure of development and implementation of forecasting, analytical and program documents of strategic development;

- documents of strategic development of territories.

Under the analysis of the documents of the second group we have examined the development strategy of subjects of the North-West Federal District.

The results of the analysis of all these groups of documents are presented in the section "Systematization of clusters as a tool for regional development".

\section{RESULTS AND DISCUSSION}

\section{Problems in innovation}

The results of calculations of integral indexes of innovative opportunities, results of innovation activity, and demand for innovation for 2005 and 2010 are shown in Fig. 1, 2, 3.

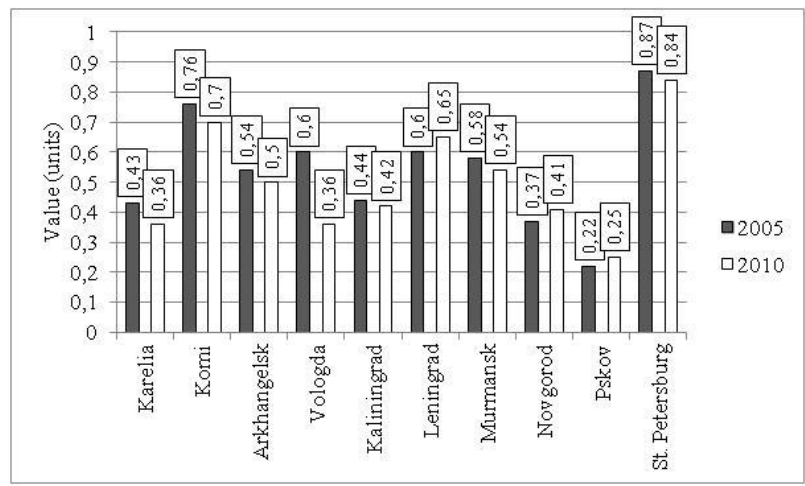

Fig. 1. Integral index of innovation opportunities of subjects of the North-West Federal District in 2005 and 2010

The highest index value of innovation opportunities in 2010, is typical for the St. Petersburg (0.84), slightly lower for the Republic of Komi (0.70). The smallest value of the integral index calculated is typical for the Pskov region (0.25). It is worth noting that in the leading regions innovation potential decreased slightly compared to 2005, and in the Pskov region, on the contrary, increased, although this did not change the place of the region among other subjects of the North-West. 


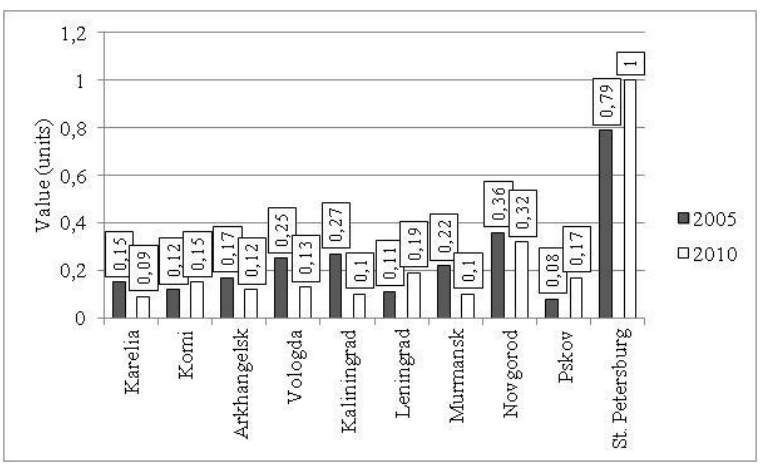

Fig. 2. Integral index of results of innovation activity of subjects of the North-West Federal District in 2005 and 2010

In 2010, innovative activity was the most effective in the St. Petersburg (IP = 1), the least efficient - in the Republic of Karelia (0.09). If compared to 2005, St. Petersburg as the region-leader has considerably strengthened its position in this rating $(+0.21)$, and the subjects of the Russian Federation, located at the end of the list, even more reduced the integral result of innovative activity.

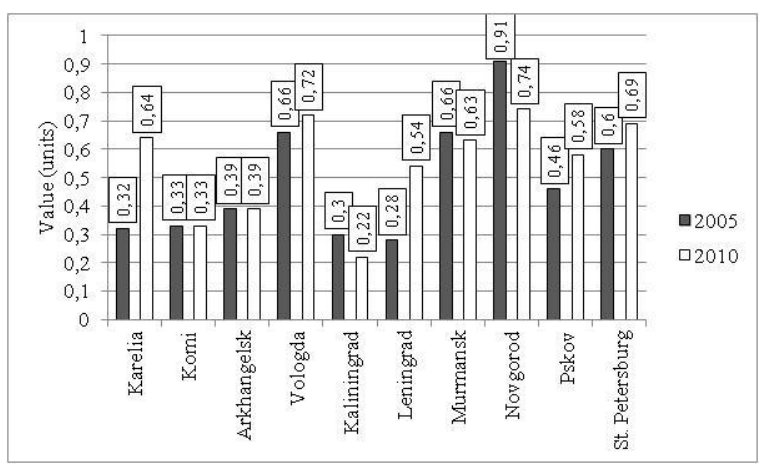

Fig. 3. Integral index of demand for innovation of subjects of the North-West Federal District in 2005 and 2010

The analysis showed that the greatest demand for innovation in 2010 is typical for the Novgorod (0.74), Vologda (0.72) Region and Saint Petersburg (0.69). The smallest value of demand for innovation is typical for the Republic of Komi (0.33) and the Kaliningrad region (0.22). It should also be noted that the growth of demand for innovation in comparison with 2005 is typical for half of the subjects of North-West, except for the Novgorod (down 0.17 of IP), Kaliningrad (down 0.08) and Murmansk (down 0.02) region. At the same time in the Arkhangelsk region and the Republic of Komi integral index of demand for innovation has not changed.

Thus, the analysis showed that the following problems are characteristic of most of the subjects of the North-West:

- high degree of differentiation of regions on the index of innovation opportunities, as well as low level of implementation of the innovative potential of the regions, which is manifested in the low indicators of results of innovation activity;

- low value of the demand for innovation in the regions with high potential for innovation;
- mismatch of demand for innovation his suggestion in the relevant regions of Russia.

These problems are mainly due to insufficient use of the cluster approach in the formation of innovation development strategy at the regional level. Use of this tool, in our opinion, will help to resolve these problems, and will open wide perspectives of development of innovative activity in the regions of Russia, which are the following positive changes:

- maximum use of the subjects of the Russian Federation of its innovation potential;

- satisfaction of internal demand for innovation through the implementation of innovation opportunities of the regions;

- qualitative improvement of the indicators of results of innovative activity of the subjects of the Russian Federation.

\section{Systematization of clusters as a tool for regional development}

Analysis of policy documents of the federal, as well as macro-regional level regarding issues of strategy of innovative development showed that the transition to an innovative model of development at the regional level is largely related with the formation of clusters:

- High-tech clusters in urban areas;

- Clusters focused on the deep processing of raw materials and energy with the use of modern technologies in underdeveloped areas;

- Tourist and recreational clusters in areas with unique natural and climatic conditions;

- Transport and logistics clusters in areas with favorable geographical position.

Great attention to the practical issues of creating clusters is also paid to the regional level. The analysis showed that certain aspects of the creation of innovation clusters is more refined in the following documents of the North-West Federal District Kaliningrad, Murmansk, Novgorod Region, St. Petersburg. These aspects include not only the selection of priority clusters (as in most of the NorthWest), but also the availability of certain provisions in the documents to encourage the construction of clusters. The issues of creating innovative clusters is elaborated only in the documents of St. Petersburg.

In Arkhangelsk and Vologda major innovative universities become a basis for formation of innovation clusters: in the Arkhangelsk region - North Federal University, in the Vologda region - Vologda State Technical University.

In the documents of the Republic of Karelia factors contributing to formation of clusters at the regional level are presented: increased knowledge sharing and experience intensification of cross-border co-operation and cross-border flows of investment, availability of advanced educational and research organizations and large firms, attractive living conditions and business environment. 
Activities aimed at creation and development of innovation clusters are best reflected in the legal and regulatory framework of St. Petersburg, and include:

- competition on the organization of the Prize of the Government of St. Petersburg for the best innovative project in the framework of clusters;

- procurement of innovative products of cluster of health, environmental, instrumentation and biotechnology for health needs of St. Petersburg;

- provision of subsidies to legal entities registered in the territory of St. Petersburg, on compensation of expenses for the purchase of production and processing equipment in connection with the activities of the cluster;

- a project of creating a centre of prototyping.

As already mentioned, in the most regions of NorthWest aspects of the creation of innovation clusters include only a selection of cluster-specific priorities. We systematized cluster priorities of subjects of the North-West (Table 1).

TABLE 1.

CLUSTER PRIORITIES OF SUBJECTS OF THE NORTH-WEST

\begin{tabular}{l|l}
\hline Subject of the North-West & Cluster priorities of subjects of the North-West \\
\hline Arkhangelsk Region & Shipbuilding, mechanical engineering, forestry, transport, tourism. \\
\hline Vologda Region & Construction, forestry, agriculture, flax, tourism. \\
\hline Kaliningrad & $\begin{array}{l}\text { Food processing, furniture production, building materials, shipbuilding and repair, amber } \\
\text { production and design, retail chains. }\end{array}$ \\
\hline Leningrad Region & $\begin{array}{l}\text { Transportation and logistics, automotive and auto components, timber processing, building } \\
\text { materials, chemical and petrochemical cluster, food industry. }\end{array}$ \\
\hline Murmansk region & $\begin{array}{l}\text { Maritime activity, mining and metallurgical, mining and chemical, transportation and logistics, } \\
\text { fishing industry and aquaculture, tourism. }\end{array}$ \\
\hline Novgorod region & Automotive components, logistics, peat, timber and flax. \\
\hline Pskov region & $\begin{array}{l}\text { Agro-industrial, transport and logistics, flax, timber, electrical and mechanical engineering, tourism, } \\
\text { a cluster of local fuels [4]. }\end{array}$ \\
\hline Republic of Karelia & Forestry, tourism, mining. \\
\hline Republic of Komi & Fuel, timber, individual cluster of low-rise housing. \\
\hline St. Petersburg & $\begin{array}{l}\text { High-tech industry, transport, tourism, science, education, finance and credit, insurance, trade, } \\
\text { information and communication. }\end{array}$ \\
\hline
\end{tabular}

Table 1 shows that in strategic documents of development of the most of subjects of the NorthWest specific clusters were identified, which could become a driving force of innovation development of the regional economy.

The following industry clusters are the most common ones in the regions of North-West: forest (except for St. Petersburg and the Murmansk region), tourism (with the exception of the Republic of Komi and the Leningrad region). Engineering cluster is also frequently mentioned in Arkhangelsk, Kaliningrad, Leningrad, Novgorod, Pskov regions and the Republic of Karelia. Transport (transport and logistics) cluster is mentioned in documents of St. Petersburg, Pskov, Murmansk, Arkhangelsk, Kaliningrad, Leningrad regions.

Territorial clusters are associations of companies, suppliers of equipment and component parts, specialized production and support services, research and educational organizations, linked by relations of territorial proximity and functional dependence in the production and sale of goods and services. At the same time clusters can be placed in either one or several regions of the Russian Federation.

In addition to regional and interregional clusters represented in the strategic documents of subjects of the Russian Federation a number of interregional cluster is mentioned in the Strategy of Development of the North-West Federal District (Table 2).
Table 2 shows that the relationship between the enterprises and organizations of the cluster can be organized in different ways, depending on the location of the regions in which to place enterprises of the industry is profitable; the economic and geographical situation of the territory, in particular the transport accessibility; the availability of a large and powerful development centre, around which enterprises of cluster are grouped (for example, for the North-West Federal District such a centre is St. Petersburg), and other factors [5].

Currently, the use of the cluster approach has taken one of the key places in strategy of socioeconomic development of a number of Russian regions and municipalities. A number of territorial clusters development projects is implemented proactively [1].

At the same time, only a relatively small part of the projects of cluster development has reached the stage of practical implementation. Work has not started for a number of priority directions of the cluster policy:

- mechanisms of methodological, information, consultation and educational support of cluster development are not created;

- there is no necessary coordination of federal executive authorities, executive bodies of subjects of the Russian Federation and local self-government, business associations to implement cluster policy;

tools of financial support of cluster projects from budget sources is limited. 
TABLE 2.

INTEGRATION OF SCIENCE AND INNOVATION CLUSTERS IN THE NORTH WEST FEDERAL DISTRICT

\begin{tabular}{|c|c|c|}
\hline $\begin{array}{l}\text { Type of } \\
\text { complexing } \\
\text { connections }\end{array}$ & $\begin{array}{l}\text { Science and } \\
\text { innovation profile of } \\
\text { cluster relations }\end{array}$ & $\begin{array}{l}\text { Subjects of North- } \\
\text { West Federal } \\
\text { District }\end{array}$ \\
\hline \multirow{7}{*}{$\begin{array}{l}\text { Radially oriented } \\
\text { interregional } \\
\text { complexing } \\
\text { connections }\end{array}$} & Shipbuilding cluster & $\begin{array}{l}\text { St. Petersburg, } \\
\text { Arkhangelsk and } \\
\text { Murmansk regions }\end{array}$ \\
\hline & $\begin{array}{l}\text { Mechanical } \\
\text { engineering cluster }\end{array}$ & St. Petersburg \\
\hline & $\begin{array}{l}\text { Cluster of information } \\
\text { and communication } \\
\text { technologies }\end{array}$ & $\begin{array}{l}\text { St. Petersburg, } \\
\text { Republic of } \\
\text { Karelia, Novgorod } \\
\text { region }\end{array}$ \\
\hline & $\begin{array}{l}\text { Nanotechnology } \\
\text { cluster }\end{array}$ & $\begin{array}{l}\text { St. Petersburg, the } \\
\text { Republic of Komi }\end{array}$ \\
\hline & $\begin{array}{l}\text { Cluster of nuclear } \\
\text { technology }\end{array}$ & $\begin{array}{l}\text { Saint-Petersburg, } \\
\text { Leningrad region }\end{array}$ \\
\hline & $\begin{array}{l}\text { Automotive cluster } \\
\text { (forming) }\end{array}$ & $\begin{array}{l}\text { Saint-Petersburg, } \\
\text { Leningrad region }\end{array}$ \\
\hline & $\begin{array}{l}\text { Cluster of scientific } \\
\text { support of agriculture }\end{array}$ & $\begin{array}{l}\text { Saint-Petersburg, } \\
\text { Leningrad region }\end{array}$ \\
\hline \multirow[t]{2}{*}{$\begin{array}{l}\text { Peripherally } \\
\text { oriented } \\
\text { interregional } \\
\text { complexing } \\
\text { connections }\end{array}$} & Timber cluster & $\begin{array}{l}\text { The Republic of } \\
\text { Karelia, the } \\
\text { Republic of Komi, } \\
\text { Vologda and } \\
\text { Arkhangelsk } \\
\text { regions }\end{array}$ \\
\hline & $\begin{array}{l}\text { Cluster of technology } \\
\text { development of } \\
\text { fisheries and } \\
\text { aquaculture }\end{array}$ & $\begin{array}{l}\text { Arkhangelsk and } \\
\text { Murmansk regions }\end{array}$ \\
\hline $\begin{array}{l}\text { Regionally } \\
\text { localized } \\
\text { complexing } \\
\text { connections }\end{array}$ & $\begin{array}{l}\text { Geological basis of } \\
\text { sustainable } \\
\text { development }\end{array}$ & Kaliningrad region \\
\hline
\end{tabular}

\section{CONCLUSION}

The study showed that the regions of the NorthWest of Russia is characterized by high degree of differentiation on the index of innovation opportunities, low level of implementation of the innovative potential, low value of the demand for innovation, mismatch of demand for innovation his suggestion, because of the insufficient use of the cluster policy instruments.

The main objective of the cluster policy is to ensure high rates of economic growth and diversification of the economy by improving the competitiveness of enterprises, suppliers of equipment, parts, specialized production and support services, research and educational organizations, forming the territorialproduction clusters.
The analysis showed that the following industry clusters are the most common ones in the regions of North-West: forest, tourism, engineering and transport.

But in order to effectively develop these clusters in the subjects of the North-West the main tasks of the cluster policy of the regions should be as follows.

1. Creating conditions for effective organizational development of clusters, including the identification of members of the cluster, the cluster development strategy.

2. Providing effective support for projects aimed at improving the competitiveness of the cluster members, at the expense of focusing and coordination, according to the priorities of development of clusters and economic policy measures.

3. Providing an effective methodology, information and consulting and educational support to the implementation of cluster policy at regional and branch level.

Results of the implementation of cluster policy is the growth of productivity and innovation activities of enterprises in the cluster and increasing the intensity of development of small and medium enterprises, the activation of direct investments, ensuring accelerated socioeconomic development of clusters based regions.

Implementation of cluster policy requires effective interaction of federal executive authorities, executive bodies of subjects of the Russian Federation and local self-government bodies and business associations.

\section{ACKNOWLEDGMENTS}

This study was supported by the Russian Humanitarian Research Foundation (RHRF). Project No 13-12-60003/13.

\section{REFERENCES}

[1] Order of the Government of RF «About the Approval of the Strategy of Innovative Development of the Russian Federation up to 2020» from 8.12.2011 № 2227-r.

[2] Kazantsev S. Assessment of the potential and scale of innovation activities in the subjects of Russian Federation. Innovations, 8, 2012, pp. 36-45.

[3] Regions of Russia. Socio-economic indicators [electronic resource]. The website of the Federal State Statistics Service. Mode of access: http://www.gks.ru/wps/wcm/connect/rosstat/rosstatsite/main/ publishing/catalog/statisticCollections/doc_1138623506156.

[4] Nikolaev M., Malyshev D. The mechanism of management of regional project of high-tech cluster formation. Bulletin of the Novgorod State University. Ser.: Economic Science, 69, 2012, pp. 27-32.

[5] Makhotaeva M., Nikolaev M., Malyshev D. Methodological aspects of formation of innovation development strategy at the regional level: monograph. Pskov. PskovGU Publishing, 2013, $296 \mathrm{p}$. 